\title{
DETERMINASI EFISIENSI TEKNIS PENGGUNAAN FAKTOR PRODUKSI PADA USAHATANI PADI LAHAN IRIGASI KABUPATEN LOMBOK BARAT
}

\author{
HERNAWATI ${ }^{\text {1) }}$, I MADE ANGGAYUDA PRAMADYA SUDANTHA ${ }^{2)}$ \\ ${ }^{1,2)}$ Dosen PS Agroteknologi Fakultas Pertanian UNW Mataram \\ e-mail : ernawati68459@gmail.com
}

\begin{abstract}
ABSTRAK
Penelitian ini bertujuan untuk mengetahui : 1). tata cara penggunaan faktor produksi, 2). faktor produksi yang mempengaruhi secara signifikan terhadap tingkat produksi pada usahatani padi, 3). tingkat efisiensi teknis pada penggunaan faktor produksi, 4). faktor-faktor penentu tingkat efisiensi teknis, 5). besarnya pengeluaran dan pendapatan yang diperoleh petani dari usahatani padi di lahan irigasi di Kabupaten Lombok Barat. Analisis yang digunakan pada penelitian ini adalah analisis deskriptif, analisis regresi linier berganda dengan fungsi Cobb Douglass dan analisis frontier.

Hasil penelitian menunjukkan bahwa 1).usahatani padi dilahan irigasi dilakukan pada MH dan MKI, dengan sistem tanam monokultur. Terjadi pemborosan di dalam pemakaian benih karena penggunaannya lebih dari rekomendasi, varietas yang dominan adalah Invari 32.Selanjutnya pada tahap pengolahan lahan dan penanaman penggunaan tenaga kerja terbesar yaitu 40 HKO.Pemakaian pupuk belum berimbang dan tidak tepat dosis 2). Faktor-faktor produksi yang secara signifikan mempengaruhi tingkat produksi pada usahatani padi di lahan irigasi adalah luas lahan, benih, pupuk (Urea + SP36) dan pestisida 3). Rata-rata tingkat efisiensi teknis yang dicapai adalah 0,899 (89,9\%), artinya, rata-rata produktivitas yang dicapai adalah sekitar 90 persen 4). Faktor-faktor yang mempengaruhi secara signifikan tingkat efisiensi penggunaan factor produksi adalah jumlah bidang persil, pengalaman berusaha tani, pendidikan kepala keluarga dan frekuensi tanam dalam satu tahun karena nilai t-hitung lebih besar dari t-tabel 1,96. 5). Pendapatan yang di terima petani dari usahatani padinya adalah Rp.9. 278.200,-/hektar dengan biaya produksi yang harus dikeluarkan rata-rata per hektar sebesar Rp. 8.081.800,- Oleh karenanya usahatani padi di lahan irigasi menguntungkan secara ekonomi karena nilai efisiensi usahanya $(\mathrm{R} / \mathrm{C}) 1,15$.
\end{abstract}

Kata kunci : Determinasi, efisiensi, faktor produksi, usahatani, padi

\section{ABSTRACT}

This study aims to find out: 1). procedures for using production factors, 2). production factors that significantly influence the level of production in rice farming, 3). level of technical efficiency in the use of production factors, 4). determinants of the level of technical efficiency, 5). the amount of expenditure and income earned by farmers from rice farming on irrigated land in West Lombok Regency. The analysis used in this study is descriptive analysis, multiple linear regression analysis with Cobb Douglass function and frontier analysis.

The results show that 1) irrigated rice cultivation is carried out in MH and ICM, with a monoculture planting system. There is a waste in the use of seeds because the use is more than a recommendation, the dominant variety is Invari 32. Then at the stage of land processing and planting the biggest use of labor was $40 \mathrm{HKO}$. The use of fertilizer was not balanced and not exactly dose 2). Production factors that significantly affect the level of production in rice farming in irrigated land are land area, seeds, fertilizer (Urea + SP36) and pesticides 3). The average level of technical efficiency achieved is 0.899 (89.9\%), meaning that the average productivity achieved is around 90 percent 4). Factors that significantly influence the level of efficiency in the use of production factors are the number of parcels, farming experience, education of the household head and the frequency of planting in one year because the t-count value is greater than t-table 1.96. 5). The income that farmers receive from their rice farming is Rp. 9. 278,200, - / hectare with production costs that must be spent on average per hectare of $R p .8,081,800$, - Therefore rice farming in irrigated land is economically beneficial because of the value of its business efficiency $(R / C)$ 1.15.Keywords: Determination, efficiency, production factors, farming, rice 


\section{PENDAHULUAN}

\section{Latar Belakang}

Tanaman pangan yang sampai saat ini dianggap sebagai komoditi terpenting dan strategis bagi perekonomian Indonesia adalah padi, karena selain merupakan tanaman pokok bagi sebagian besar petani, juga merupakan bahan makanan pokok bagi penduduk Indonesia. Bangsa Indonesia telah lama mengenal tata carabercocok tanam padi. Menurut sejarah, padi dikenal dan ditanam orang sejak zaman Hindu atau bahkan sebelumnya.Pada umumnya masing-masing daerah mempunyai jenis jenis padi sendiri.Jenis padi itu berbeda antara satu daerah dengan yang lainnya. Perbedaannya terletak pada umur tanaman, banyaknya hasil, mutu beras dan tahan tidaknya tanaman terhadap gangguan hama dan penyakit.

Provinsi Nusa Tenggara Barat merupakan daerah penghasil padi dan sebagai daerah untuk pengadaan stok pangan nasional, dengan berbagai program yang dilaksanakan seperti Bimas, Inmas, Insus, Gogo rancah dan Supra Insus. Programprogram tersebut berhasil meningkatkan produksi dan berswasembada beras bahkan surplus sehingga dapat mengekspor ke berbagai propinsi di tanah air (Dinas Pertanian Tanaman Pangan Propinsi NTB, 2001).

Tabel 1.Perkembangan Luas Panen, Rata-rata Produksi dan Produksi Padi di Propinsi Nusa Tenggara Barat Tahun 2011-2015

\begin{tabular}{|c|c|c|c|}
\hline Tahun & $\begin{array}{c}\text { Luas Panen } \\
\text { (Ha) }\end{array}$ & $\begin{array}{c}\text { Produktivitas } \\
\text { (Ku/Ha) }\end{array}$ & $\begin{array}{c}\text { Produksi } \\
\text { (Ton) }\end{array}$ \\
\hline 2011 & 418.062 & 49,45 & 2.067 .137 \\
2012 & 425.448 & 49,69 & 2.114 .231 \\
2013 & 438.057 & 50,08 & 2.193 .698 \\
2014 & 433.712 & 48,80 & 2.116 .637 \\
2015 & 467.503 & 51,71 & 2.417 .392 \\
\hline
\end{tabular}

Sumber :Badan Pusat Statistik Provinsi Nusa Tenggara Barat, Tahun 2016.

Produksi padi pada tahun 2015 di Propinsi Nusa Tenggara Barat mencapai hasil sejumlah 2.417.392 ton dengan luas panen 467.503 hektar, sehingga rata-rata produksi sebesar 51,71 kw per hektar. Bila dibandingkan dengan tahun-tahun sebelumnya terlihat adanya peningkatan produksi sekitar 6,74 persen. Hal ini disebabkan oleh meningkatnya luas panen sebesar 7,85 persen. Tingkat produktivitasnya per hektar terlihat adanya peningkatan sebesar 1,21 persen. Dengan meningkatnya jumlah penduduk dan dibutuhkannya cadangan pangan yang setiap tahunnya semakin besar, maka sasaran produksi berikutnya harus terus diusahakan.

Salah satu kabupaten yang menjadi penyumbang padi di Propinsi NTB adalah Kabupaten Lombok Barat. Pada tahun 2015, luaspanen padi di kabupaten ini seluas 32.940 hektar. Jika dibandingkan dengan luas panen tahun sebelumnya terjadi peningkatan sebesar 2.094 hektar atau naik sebesar 5,17\%. Produksi padi pada tahun 2015 mencapai 171.645 ton, naik sebesar 2.457 ton atau naik sebesar 4,97\% dibanding tahun sebelumnya. Hal ini disebabkan oleh meningkatnya luas panen yang awalnya seluas 30.846 hektar menjadi 32.940 hektar. Dari tingkat produktivitas per hektar terlihat adanya penurunan sebesar 0,21 persen yaitu produktivitas tahun sebelumnya sebesar 54,17 kuintal per hektar menjadi 52,11 kuintal per hektar. Ini menunjukkan para petani padi belum melaksanakan upaya optimal untuk meningkatkan produksi padi.

Rahmayati (2008) menyatakan bahwa belum-optimalnya produktivitas padi di lahan sawah, antara lain disebabkan oleh rendahnya efisiensi pemupukan, belum efektifnya pengendalian hama dan penyakit, penggunaan benih yang kurang optimal, kekeringan pada periode pertumbuhan tertentu, drainase tanah sering kurang baik, dan penanganan panen dan pasca panen kurang optimal.

Mengkaji persoalan tentang produktivitas sebenarnya mengkaji masalah efisiensi karena ukuran dari produktivitas pada hakekatnya adalah seberapa besar keluaran dapat dihasilkan per unit masukan tertentu.Jika faktor harga diasumsikan given, efisiensi teknis pada akhirnya menentukan pendapatan petani.

Dalam pengelolaan usahataninya, petani berhadapan dengan bagaimana mengalokasikan input secara tepat (efisien) untuk mencapai maksimasi keuntungan. Peranan input bukan hanya dapat dilihat dari segi macamnya atau ketersediaannya dalamwaktu yang tepat, tetapi dapat juga dilihat dari efisiensi penggunaan faktor produksi tersebut, sehingga bagaimana petani melakukan usahatani secara efisien adalah upaya 
yang sangat penting. Bila petani mendapatkan keuntungan yang besar dan usahataninya, misalnya karena pengaruh harga maka petani tersebut dapat dikatakan mengalokasikan faktor produksinya secara efisiensi atau efisiensi harga (Soekartawi, 1987).

\section{Rumusan Masalah}

Permasalahannya adalah seberapa tinggi efisiensi penggunaan input dan kombinasi berbagai input yang diterapkan petani di lahan sawahnya dan faktor apa saja yang berpengaruh signifikan terhadap tingkat efisiensi ini.

\section{Tujuan Penelitian}

Tujuan penelitian ini adalah untuk mengetahui tata cara penggunaan faktor produksi pada usahatani padi di lahan irigasi, Untuk mengetahui faktor produksi yang mempengaruhi secara signifikan terhadap tingkat produksi pada usahatani padi, Untuk mengetahui tingkat efisiensi teknis pada penggunaan faktor produksi pada usahatani padi, Untuk mengetahui faktor-faktor penentu tingkat efisiensi teknis pada penggunaan faktor produksi pada usahatani padi dan untuk mengetahui besarnya pengeluaran dan pendapatan yang diperoleh petani dari usahatanipadi di lahan irigasi di Kabupaten Lombok Barat.

\section{METODOLOGI PENELITIAN}

Penelitian ini menggunakan metode deskriptif yang bertujuan untuk membuat gambaran suatu keadaan secara sistematis, faktual dan akurat mengenai fakta-fakta dan sifatsifat, dan hubungan antara fakta yang diteliti untuk mendapatkan makna/implikasi dari suatu masalah yang dipecahkan Nasir (1981) dan Supranto (2003), yang dilaksanakan di Kecamatan Narmada, Gerung, Labuapi dan Kediri secara Purposive Sampling atas pertimbangan bahwa empat kecamatan ini memiliki luas lahan terbesar dan menerapkan usahatani padi di lahan irigasi sepanjang tahun. Sampel responden ditentukan secara Accidental Sampling, masing masing desa ditentukan secara Quota Sampling sebanyak 25 orang petani, sehingga jumlah seluruh responden dalam penelitian ini adalah 100 orang.

Untuk mengetahui tata cara penggunaan faktor produksi pada usahatani padi di lahan irigasi digunakan analisis deskriptif, Untuk mengetahui faktor produksi yang signifikan menentukan tingkat produksi usahatani padi di lahan sawah irigasi digunakan analisis linier berganda (Multiple Linear Regression). Alat analisis yang dipergunakan untuk mengetahui efisiensi penggunaan input produksi dalam proses produksi usahatani padi sawah lahan irigasi adalah menggunakan analisis Frontier.

$$
\ln y=\ln \beta_{0}+\sum_{k=1}^{7} \beta_{k} \ln x_{k i}+V_{i}-U_{i} ; V_{i}-N\left(0, \sigma_{v}^{2}\right)
$$

Model analisis regresi linier berganda yang diaplikasikan dalam penelitian ini adalah $\mathrm{TE}=\delta_{0}+\delta_{1} \mathrm{Z}_{1}$ $+\delta_{2} \mathrm{Z}_{2}+\delta_{3} \mathrm{Z}_{3}+\delta_{4} \mathrm{Z}_{4} \delta_{5} \mathrm{Z}_{5}+\delta_{6} \mathrm{Z}_{6}+\delta_{7} \mathrm{Z}_{7}$, Untuk menganalisis besarnya pendapatan pada usahatani padi lahan irigasi di Kabupaten Lombok Barat dilakukan analisis biaya dan pendapatan dengan rumus (Soekartawi, 2002):

$$
I=T R-T C
$$

\section{HASIL DAN PEMBAHASAN}

\section{Tata Cara penggunaan Faktor Produksi pada Usahatani Padi}

Sebagaimana yang telah dipaparkan di ruang lingkup penelitian bahwa subyek penelitian adalah petani yang mengusahakan usahatani padi di lahan sawah irigasi MT. 2016/2017, maka tata cara penggunaan faktor produksi yang dimaksud disini adalah tata cara penggunaan dan kebutuhan input pada setiap tahapan usahatani padi pada MT. 2016/2017.

\section{Penyiapan Benih}

Pada kegiatan penyiapan benih terdapat 3 aktivitas (1) pemilihan benih, (2) penyemaian benih, (3) pemeliharaan pembibitan. Dari beberapa varietas benih yang ada dipasaran, $90 \%$ atau 90 orang petani memilih menggunakan benih varietas Invari 32, $10 \%$ atau 10 orang petani menggunakan varietas Invari 31. 
Alasan petani memilih varietas invari 32 adalah karena benih dapat tumbuh lebih cepat dan tegar, lebih tahan terhadap hama wereng, jumlah anakan banyak dan rasa nasinya lebih disukai masyarakat.

\section{Pengolahan Lahan dan Penanaman}

Pengolahan tanah yang dilakukan petani adalah membajak sawah untuk membalik tanah dan memasukkan bahan organik yang ada di permukaan. Umumnya bajak dan garu dilakukan traktor dengan sistem borongan dengan jumlah tenaga kerja yang digunakan 24,99 HKO. Bibit ditanam dengan jarak tanam pada kisaran 20x20 cm,rata-rata tenaga kerja yang digunakan adalah 14,89 HKO. Jadi total penggunaan tenaga kerja pada tahapan ini adalah 39,88 HKO.

\section{Pemeliharaan}

Pemeliharaan yang dilakukan petani responden adalah penyulaman, penyiangan, pengairan, pemupukan, dan pengendalian hama penyakit dan gulma.Tenaga kerja yang digunakan pada penyulaman adalah 1 HKO.Penyiangan dilakukan dengan menggemburkan tanah bertujuan meningkatkan udara didalam tanah dan merangsang pertumbuhan akar padi lebih baik.Penyiangan dilakukan dua kali yaitu pada saat berumur 20-25 hari dan 40-45 hari setelah tanam dengan menggunakan landak. Tenaga kerja yang digunakan saat penyiangan adalah 15,77 HKO. Pemupukan, pupuk yang digunakan oleh petani adalah pupuk Urea dan SP36 dengan takaran Urea : $300 \mathrm{~kg} / \mathrm{ha}, \mathrm{SP} 36: 75-150 \mathrm{~kg} / \mathrm{ha}$ dan KCL : $50 \mathrm{~kg} / \mathrm{ha}$.

Pengendalian hama dan penyakit dari 100 orang jumlah petani responden 86 orang (86\%) tidak menggunakan pestisida. Sisanya menggunakan pestisida jenis Prevathon sebanyak 4 orang, Trisula 2 orang, Sidatan 3 orang, dan Sidador 4 orang serta paradon sebanyak 1 orang. Kegiatan pengendalian hama ini dilakukan sewaktu-waktu dan karena pada musim tanam tersebut kondisi pertanaman baik maka jumlah tenaga kerja yang digunakan cukup dari dalam keluarga adalah 1,23 HKO.

\section{Faktor Produksi yang Mempengaruhi Tingkat Produksi Usahatani Padi}

Hasil pendugaan koefisien regresi usahatani padi menunjukkan besarnya perubahan produksi dari setiap input yang digunakan. Ini berarti untuk mengukur satuan perubahan output (produksi) terhadap perubahan input (faktor) produksi yang ditambahkan dengan asumsi yang lain konstan. Hasil analisis dengan fungsi linier menunjukkan hasil dengan $\mathrm{R}^{2}$ sebesar 0,679 dan F-value sebesar 40,149 dan hasil koefisien regresi parsial pada tingkat kepercayaan 95\% dengan empat variabel yang signifikan, terdiri dari luas lahan, bibit, pupuk (Urea + SP36), dan pestisida.

Tabel 2. $\quad$ Uji Koefisien Regresi Linier Berganda Petani Responden pada Usahatani Padi di Lahan Irigasi MT. 2016/2017 di Kabupaten Lombok Barat

\begin{tabular}{|l|r|r|r|c|}
\hline \multicolumn{1}{|c|}{ Variabel } & $\begin{array}{c}\text { Koefisien } \\
\text { Regresi }\end{array}$ & Standar Eror & t-hitung & Ket. \\
\hline Intercept & -2.205 & 1,116 & $-1,98$ & \\
Luas lahan $\left(\mathrm{X}_{1}\right)$ & 12.849 & 2,547 & 5,04 & Signifikan \\
Tenaga Kerja $\left(\mathrm{X}_{2}\right)$ & -.118 & 0,142 & $-0,83$ & \\
Benih $\left(\mathrm{X}_{3}\right)$ & 1,068 & 0,638 & 2,68 & Signifikan \\
Urea+Za $\left(\mathrm{X}_{4}\right)$ & .090 & 0,158 & 2,57 & Signifikan \\
SP36 $\left(\mathrm{X}_{5}\right)$ & .050 & 0,123 & 2,41 & Signifikan \\
Pestisida $\left(\mathrm{X}_{6}\right)$ & 1.579 & 1,822 & 0,87 & Signifikan \\
$\mathrm{R}^{2}$ & 0,68 & & & \\
F-Value & 40,15 & & & \\
t-tabel & 1,96 & & & \\
\hline Jumlah sampel (N) & 100 & & & \\
\hline
\end{tabular}

Dari Tabel 2 di atas diketahui bahwa dalam pengujian pada taraf nyata 95\% dengan F-hitung $(40,57)$ lebih besar dari pada F-tabel $(2,05)$ yang berarti secara bersama-sama variabel bebas (Independent variabel) berpengaruh nyata terhadap variabel terikat (Dependent Variabel), dengan kata lain tingkat produksi padi secara bersama-sama dipengaruhi oleh luas lahan, benih, pupuk (Urea+SP36) dan pestisida. 
Dari hasil analisis fungsi linier berganda didapatkan nilai koefisien determinasi $\left(\mathrm{R}^{2}\right)$ sebesar 0,68 yang berarti 68\% dari keragaman hasil produksi padi (Variabel Dependent) dapat dijelaskan oleh variabel-variabel bebas (Indevendent Variabel) dalam model yang meliputi variabel luas lahan, benih, Urea, SP36, dan pestisida. Sisanya $32 \%$ ditentukan oleh faktor-faktor lain diluar model.

Berdasarkan hasil uji koefisien regresi linier terlihat bahwa hubungan antara variabel bebas dan terikat sangat kuat kecuali pada variabel tenaga kerja memiliki hubungan sangat lemah.Pengaruh dari masingmasing variabel bebas terhadap variabel terikat dapat diuraikan sebagai berikut.

\section{Luas lahan $\left(\mathbf{x}_{1}\right)$}

Hasil uji parsial pada tingkat kepercayaan 95\% menunjukkan bahwa koefisien luas lahan berpengaruh nyata terhadap tingkat produksi dimana diketahui nilai t-hitung $(5,04)$ lebih besar daripada t-tabel $\alpha 5 \%$ $(1,96)$. Nilai koefisien variabel luas lahan yang diperoleh memberikan nilai koefisien regresi yang positif sebesar 12,85 yang artinya setiap penambahan satu hektar luas lahan akan menyebabkan kenaikan hasil produksi padi sebesar 12,85 kw dengan variabel lain dianggap tetap.

\section{Benih ( $\left.\mathbf{x}_{3}\right)$}

Hasil uji parsial pada tingkat kepercayaan $95 \%$ untuk benih $\left(\mathrm{X}_{3}\right)$ diperoleh nilai t-hitung sebesar 2,68 dan t-tabel sebesar 1,96\%, menunjukkan bahwa koefisien pemakian benih berpengaruh nyata terhadap tingkat produksi. Nilai koefisien regresi variabel benih diperoleh sebesar 1,068 yang artinya setiap penambahan satu kilogram penggunaan benih akan menyebabkan kenaikan hasil produksi padi sebesar 1,068 kw dengan variabel lain dianggap tetap. Hal ini menunjukkan bahwa penggunaan benih pada saat ini masih dapat ditingkatkan.

\section{Pupuk Urea $\left(\mathbf{x}_{4}\right)$}

Pupuk adalah salah satu sarana produksi yang paling penting dalam meningkatkan nilai produksi termasuk didalamnya Urea yang digunakan sebagai pupuk dasar dalam usahatani padi. Nilai koefisien regresi pupuk Urea pada tingkat kepercayaan 95\% didapatkan sebesar 0,090 yang berarti bahwa setiap penambahan pupuk urea satu kilogram akan memberikan peningkatan produksi sebesar 0,090 kw pada variabel lain dianggap tetap. Hasil analisis diperoleh nilai t-hitung sebesar 2,57 dan t-tabel sebesar 1,96. Hal ini menunjukkan bahwa pupuk Urea berpengaruh nyata terhadap produksi petani.Penambahan pupuk dengan dosis yang sesuai rekomendasi akan mampu meningkatkan jumlah produksi secara nyata.

\section{Pestisida $\left(\mathbf{X}_{7}\right)$}

Hasil uji parsial pestisida pada tingkat kepercayaan 95\% diperoleh nilai t-hitung sebesar 0,87 dan t-tabel sebesar 1,96 menunjukkan bahwa koefisien pemakaian pestisida berpengaruh nyata terhadap tingkat produksi. Nilai koefisien regresi variable pupuk pestisida diperoleh sebesar 0,87 yang artinya bahwa pestisida memberikan pengaruh kecil terhadap produksi. Jika dikaitkan dengan tatacara penggunaan faktor produksi diatas, kecilnya pengaruh ini karena pada kenyataannya sebagian besar petani tidak menggunakan pestisida. Karena kondisi pada saat penanaman dalam keadaan baik dan kalaupun ada hama, intensitas serangan masih kecil populasinya, artinya serangan hama masih dibawah ambang rasa sehingga belum diperlukan pestisida. Dari sisi teori, apa yang telah dilakukan petani sebagai tindakan yang benar, yaitu meminimalkan penggunaan pestisida selain mengurangi biaya yang harus dikeluarkan petani juga memberikan pengaruh yang sehat bagi lingkungan.

\section{Tingkat Efisiensi Teknis Penggunaan Faktor Produksi}

Nilai efisiensi teknis bervariasi secara merata dari 66,86\% hingga 99,86\%. Dan rata-rata tingkat efisiensi teknis yang dicapai petani dalam usahatani padi di lahan irigasi adalah $0,899(89,9 \%)$. Artinya, ratarata produktivitas yang dicapai adalah sekitar $80 \%$ dari frontier yakni produktivitas maksimum yang dapat dicapai dengan sistem pengelolaan yang terbaik. Dengan demikian petani masih memiliki peluang sekitar 10,1 persen untuk mencapai tingkat efisiensi maksimal 100 persen.

Tingkat efisiensi seperti ini tergolong kategori tinggi dan hampir sama dengan yang dicapai petani padi di Kabupaten Lombok Tengah $(0,86)$ sebagaimana yang diperoleh dari penelitian Rahmayani (2008). 
Pada kasus di lokasi penelitian ini dimana Tingkat Efisiensi Teknis rata-rata sebesar 0,89 dengan produksi rata-rata sebesar 43,40 kw/ha atau setara dengan 42,94 kw/GKG. Angka ini telah berada diatas produktivitas rata-rata nasional sebesar $42-44 \mathrm{kw} / \mathrm{GKG} / \mathrm{ha}$. Akan tetapi jika dibandingkan dengan rata-rata produktivitas yang dicapai RRC (6,3 ton) adalah lebih rendah. Begitu juga jika Tingkat Efisien Teknis mencapai 1, produksi rata-ratanya masih dibawah RRC, yaitu 55,23 kw/GKG/ha. Ini artinya bahwa produksi frontier petani responden perlu ditingkatkan minimal dapat menyamai pencapaian produktivitas RRC, misalnya dengan menggunakan teknologi baru seperti bibit hibrida varietas baru, mengembangkan teknologi budidaya padi pola SRI (system of rice intensification).

Bentuk sebaran petani menurut tingkat efisiensi yang dicapainya. Tampak bahwa dari seluruh responden yang diteliti, sebagian besar petani 80 orang $(80 \%)$ berada pada interval $0,91-0,98$ atau proporsi petani yang mendekati frontier (TE 1) yaitu berjumlah 80 orang, sedangkan yang berada dibawah 0,81 berjumlah 13 orang atau 13 persen dan berada pada kisaran 0,81-0,90 berjumlah 7 orang atau 7 persen.

\section{Determinasi Efisiensi Teknis}

Pada fungsi "TE" dari lima variabel yang merupakan determinan efisiensi terdapat empat variabel yang pengaruhnya signifikan karena nilai t-hitung yang dicapai lebih besar dari t-tabel 1,96 yaitu jumlah bidang persil $\left(Z_{1}\right)$ dengan nilai t-hitung $-3,43$, pengalaman berusaha tani $\left(Z_{4}\right)$ dimana t-hitung sebesar 1,99 dan pendidikan kepala keluarga $\left(Z_{6}\right)$ sebesar 2,40 serta frekwensi tanam $\left(Z_{7}\right)$ dengannilai t-hitung terbesar yaitu 5,14 . Sedangkan variabel umur petani walaupun bernilai positif tetapi nilai t-hitungnya $(0,101)$ lebih kecil dari t-tabel 1,96. Selanjutnya jika peranan tiap variabel yang berpengaruh nyata dicerminkan oleh nilai koefisien parameter dimana semakin besar nilainya menunjukkan bahwa variabel tersebut semakin besar peranannya terhadap efisiensi teknis usahatani padi.

Tabel 3. Hasil Estimasi Determinasi Efisiensi Teknis Usahatani Padi di Lahan Irigasi Kabupaten Lombok Barat MT. 2016/2017.

\begin{tabular}{|l|r|r|}
\hline \multicolumn{1}{|c|}{ Variabel } & \multicolumn{1}{|c|}{$\begin{array}{c}\text { Koefisien } \\
\text { Regresi }\end{array}$} & t-hitung \\
\hline Jumlah Persil $\left(\mathrm{Z}_{1}\right)$ & $-0,041$ & $-3,43$ \\
Pengalaman Berusahatani $\left(\mathrm{Z}_{4}\right)$ & 0,033 & 1,98 \\
Umur Petani $\left(\mathrm{Z}_{5}\right)$ & 0,094 & 1,01 \\
Pendidikan $\left(\mathrm{Z}_{6}\right)$ & 0,029 & 2,39 \\
Frekuensi Tanam $\left(\mathrm{Z}_{7}\right)$ & 2,23 & 5,14 \\
\hline
\end{tabular}

Dari lima variabel yang berperan terhadap tingkat efisiensi teknis, maka variabel terpenting adalah frekuensi tanam dengan nilai koefisien tertinggi yaitu 2,23 dilanjutkan dengan umur petani dengan nilai koefisien regresi 0,094 selanjutnya pengalaman berusahatani dengan nilai koefisien 0.033 dan terakhir adalah pendidikan menunjukkan nilai koefisien regresi terkecil yaitu 0,029 yang mengindikasikan bahwa tingkat pendidikan petani sebagai kepala rumah tangga tani berperan kecil terhadap tingkat efisiensi usahatani padi.

\section{Pengeluaran dan Pendapatan Usahatani Padi}

Petani didalam mengelola usahataninya pada prinsipnya bertujuan untuk memperoleh hasil sebagai balas jasa dari korbanan yang dikeluarkan. Untuk memperoleh hasil tersebut selama proses produksi berlangsung diperlukan biaya produksi sehingga akan berpengaruh terhadap pendapatan yang diperoleh.

\section{Biaya Produksi}

Biaya produksi pada usahatani padi terdiri dari biaya tetap dan biaya variabel.Biaya variabel meliputi biaya saprodi, tenaga kerja, penyusutan alat dan zakat, sedangkan biaya tetap meliputi biaya pajak dan iuran air. Semua jenis biaya diperhitungkan selama satu kali proses produksi padi. 


\section{Biaya Saprodi}

Biaya yang digunakan untuk sarana produksi dapat dilihat pada Tabel 4.sebagai berikut:

Tabel 4. Biaya Sarana Produksi per Hektar dan rata-rata per Luas lahan garapan (0,69 ha).

\begin{tabular}{|c|c|c|c|c|c|}
\hline \multirow{2}{*}{ No } & \multirow{2}{*}{ Jenis Sarana Produksi } & \multicolumn{2}{|c|}{ Pemakaian per hektar } & \multicolumn{2}{|c|}{$\begin{array}{c}\text { Pemakaian } \\
\text { per luas lahan garapan }\end{array}$} \\
\hline & & $\begin{array}{c}\text { Jumlah } \\
\text { Pemakaian }\end{array}$ & $\begin{array}{c}\text { Nilai yang } \\
\text { Dikeluarkan (Rp) }\end{array}$ & $\begin{array}{c}\text { Jumlah } \\
\text { Pemakaian } \\
\end{array}$ & $\begin{array}{c}\text { Nilai yang } \\
\text { Dikeluarkan (Rp) }\end{array}$ \\
\hline 1. & Benih $(\mathrm{Kg})$ & 50 & 450.000 & 34,38 & 309.420 \\
\hline 2. & $\begin{array}{l}\text { Pupuk } \\
\text { a. Urea }+ \text { ZA }(\mathrm{Kg}) \\
\text { b. SP36 }(\mathrm{Kg})\end{array}$ & $\begin{array}{l}300 \\
100\end{array}$ & $\begin{array}{l}585.000 \\
240.000\end{array}$ & $\begin{array}{l}204,32 \\
100,48\end{array}$ & $\begin{array}{l}398.424 \\
241.152\end{array}$ \\
\hline 3. & \begin{tabular}{ll}
\multicolumn{2}{l}{ Obat-obatan } \\
a. & Prevathon \\
b. & Trisula \\
c. & Sidatan \\
d. & Sidador \\
e. & Paradon
\end{tabular} & $\begin{array}{l}0,19 \\
0,04 \\
0,14 \\
0,02 \\
0,02\end{array}$ & $\begin{array}{r}23.750 \\
1.800 \\
35.000 \\
1.000 \\
1.500\end{array}$ & $\begin{array}{l}0.09 \\
0.02 \\
0.07 \\
0.01 \\
0.01\end{array}$ & $\begin{array}{r}11.250 \\
900 \\
17.500 \\
500 \\
7.500\end{array}$ \\
\hline
\end{tabular}

Sumber : Data primer diolah

Dari Tabel 4 di atas dapat diketahui bahwa jenis sarana produksi yang memerlukan banyak biaya adalah benih dan pupuk. Biaya sarana produksi tertinggi adalah untuk pembelian pupuk.Rata-rata biaya pupuk per hektarnya untuk Urea adalah Rp. 585.000,-, SP36 sebesar Rp. 240.000,-. Sehingga total biaya yang dikeluarkan sebesar Rp. 825.000,- Dari dua jenis pupuk anorganik yang digunakan oleh petani, biaya tertinggi yang dikeluarkan petani adalah untuk pemakaian Urea, hal ini disebabkan karena diantara jenis pupuk yang direkomendasikan, pupuk Urea merupakan yang paling dominan digunakan dalam usahatani padi, baik dilihat dari sisi dosis penggunaan maupun jumlah pengguna.

\section{Biaya Tenaga Kerja}

Biaya tenaga kerja yang dikeluarkan pada usahatani padi baik dalam keluarga maupun luar keluarga diberbagai tahapan produksi pada table 5 berikut.

Tabel 5. Rata-rata Biaya Tenaga Kerja per Hektar dan per Luas Lahan Garapan $(0,69)$ Hektar

\begin{tabular}{|c|c|c|c|c|c|}
\hline \multirow{2}{*}{ No } & \multirow{2}{*}{ Jenis Biaya Kegiatan } & \multicolumn{2}{|c|}{$\begin{array}{c}\text { Penyerapan Tenaga } \\
\text { Kerja/Ha }\end{array}$} & \multicolumn{2}{|c|}{$\begin{array}{c}\text { Penyerapan Tenaga } \\
\text { Kerja/luas lahan garapan }\end{array}$} \\
\hline & & $(\mathrm{HKO})$ & Biaya (Rp) & $(\mathrm{HKO})$ & Biaya (Rp) \\
\hline 1. & Pengolahan Lahan & 27,40 & 1.370 .000 & 18,91 & 945.000 \\
\hline 2. & Pembibitan & 207 & 103.500 & 1.43 & 71.500 \\
\hline 3. & Penanaman & 18,84 & 310860 & $1,+3$ & 214.500 \\
\hline 4. & Penyiangan & 34,16 & 1.024 .800 & 23,37 & 701.100 \\
\hline 5. & Pemupukan & 3,43 & 171.500 & 2,37 & 118.500 \\
\hline 6. & Pemberantasan Hama & 0,70 & 35.000 & 0,48 & 24.000 \\
\hline 7. & Irigasi & 2,17 & 108.500 & 1.50 & 75.000 \\
\hline 8. & Panen, rontok, ngepak & 30,40 & 1.520 .000 & 20,98 & 1.049 .000 \\
\hline 9. & Mengangkut & 2,35 & 117.500 & 1,62 & 81.000 \\
\hline \multicolumn{2}{|c|}{ Jumlah } & 121,52 & 4.760 .000 & 83,85 & 3.284 .000 \\
\hline
\end{tabular}

Sumber : data primer diolah

Dari Tabel 5.di atas dapat diketahui bahwa biaya tenaga kerja yang dikeluarkan oleh petani responden per hektar adalah sebesar Rp. 4.760.000,- dengan tingkat penyerapan tenaga kerja sebesar 121,52 HKO sedangkan rata-rata biaya tenaga kerja yang dikeluarkan oleh petani responden per luas lahan garapan sebesar Rp. 3.284.000,- dengan tingkat penyerapan tenaga kerja sebesar 83,83 HKO. Rata-rata biaya tenaga 
kerja per luas lahan garapan yang dikeluarkan oleh petani responden paling tinggi adalah pada saat panen dan pasca panen sebesar Rp. 1.049.000,- dan untuk per hektar sebesar Rp. 1.520.000,- dengan rata-rata penyerapan tenaga kerja per luas lahan garapan sebanyak 20,98 HKO dan per hektar lahan sebesar 30,40 HKO.

Dari delapan jenis kegiatan yang dilakukan petani pada saat pengelolahan lahan, ada empat jenis yang mengeluarkan biaya yang besar dan menggunakan tenaga kerja yang tinggi, antara lain pengelolahan tanah, biaya penanaman, penyiangan, panen dan pasca panen.

\section{Biaya Pajak, Zakat, Iuran Air, lain-lain}

Biaya pajak dan iuran air merupakan tetap sedangkan zakat merupakan biaya variabel yang diperhitungkan dalam satu kali proses produksi padi. Untuk lebih jelasnya dapat dilihat pada Tabel 6.berikut.

Tabel 6. Rata-rata Biaya Pajak, Iuran Air per Hektar dan per Luas Lahan Garapan (0,69 ha)

\begin{tabular}{|l|l|r|r|}
\hline \multicolumn{1}{|c|}{ No } & \multicolumn{1}{|c|}{ Jenis Biaya } & Jumlah per hektar (Rp) & \multicolumn{1}{c|}{$\begin{array}{c}\text { Jumlah per Luas Lahan } \\
\text { Garapan (Rp) }\end{array}$} \\
\hline 1. & Pajak Bumi dan Bangunan & 304.404 & 210.039 \\
2. & Iuran Air & 81.448 & 56.199 \\
3. & Zakat & 1.530 .840 & 1.056 .279 \\
\hline \multicolumn{2}{|l|}{ Jumlah } & 1.916 .692 & 1.322 .517 \\
\hline
\end{tabular}

Sumber : Data primer diolah

Dari Tabel 6. Di atas dapat diketahui bahwa biaya pajak bumi dan bangunan per hektar adalah Rp. 304.404 dan rata-rata per luas lahan garapan sebesar Rp. 210.039,- sedangkan biaya untuk iuran air per hektar sebesar Rp. 81.448,- dengan rata-rata biaya per luas lahan garapan Rp. 56.199,-. Pada kenyataannya biaya yang dikeluarkan petani bukan saja untuk dua hal diatas, tetapi juga pengeluaran untuk zakat, dan justru dari keseluruhan pengeluaran petani zakat adalah komponen biaya yang paling besar Rp. 1.530.840,per hektar atau Rp 1.322.517,- per LLG dan Zakat langsung disisihkan oleh petani pemiliknya dari hasil panennya berupa gabah.

\section{Biaya penyusutan Alat}

Biaya penyusutan alat merupakan biaya tetap yang diperhitungkan dalam satu kali proses produksi padi. Perhitungan penyusutan alat adalah harga dibagi umur ekonomis alat dikalikan umur pakai.Untuk lebih jelasnya dapat dilihat pada Tabel 7.berikut.

Tabel 7. Rata-rata Biaya Penyusutan Alat per hektar dan per Luas lahan Garapan $(0,69)$ hektar.

\begin{tabular}{|c|c|c|c|}
\hline No & Jenis Peralatan & $\begin{array}{l}\text { Nilai Penyusutan per Hektar } \\
\text { (Rp) }\end{array}$ & $\begin{array}{c}\text { Nilai Penyusutan per } \\
\text { Luas lahan Garapan } \\
\text { (Rp) }\end{array}$ \\
\hline $\begin{array}{l}1 . \\
2 .\end{array}$ & $\begin{array}{l}\text { Cangkul } \\
\text { Sabit }\end{array}$ & $\begin{array}{l}53.526 \\
13.943\end{array}$ & $\begin{array}{r}25.540 \\
6.653\end{array}$ \\
\hline & Jumlah & 67.469 & 32.193 \\
\hline
\end{tabular}

Sumber : Data primer diolah

Dari Tabel 7.di atas dapat dilihat bahwa rata-rata biaya penyusutan alat yang dimiliki petani responden permusim tanam per hektar adalah sebesar Rp. 67.469,- atau 0,84 \% dari total biaya produksi sebesar Rp. 8.081.800,- Hal ini menunjukkan bahwa biaya yang dikeluarkan petani masih tergolong rendah. 


\section{Pendapatan}

Pendapatan usahatani padi adalah nilai produksi dikurangi keseluruhan biaya yang dikorbankan oleh petani responden sampai memperoleh hasil.Produksi dan nilai produksi dari usahatani padi dapat dilihat pada Tabel 8.berikut.

Tabel 8. Rata-rata Produksi, Nilai Produksi, Biaya Produksi, Pendapatan dan R/C ratio petani responden pada Usahatani Padi di Lahan Irigasi MT. 2016/2017 Kabupaten Lombok Barat.

\begin{tabular}{|l|l|r|r|}
\hline \multicolumn{1}{|c|}{ Noraian } & Besarnya per hektar & \multicolumn{1}{|c|}{$\begin{array}{c}\text { Besarnya per Luas Lahan } \\
\text { Garapan }\end{array}$} \\
\hline 1. & Produksi (kw) & 43.40 & 29,95 \\
2. & Nilai Produksi (Rp) & 17.360 .000 & 11.978 .400 \\
3. & Biaya Produksi (Rp) & 8.081 .800 & 5.576 .442 \\
& a. Biaya tetap (Rp) & 385.852 & 266.238 \\
& b. Biaya Variabel (Rp) & 7.695 .948 & 5.310 .204 \\
4. & Pendapatan (Rp) & 9.278 .200 & 6.401 .958 \\
\hline 5. & R/C ratio & \multicolumn{2}{|c|}{} \\
\hline
\end{tabular}

Sumber : data Primer diolah

Untuk melihat pencapaian rata-rata produksi keseluruhan petani reponden di daerah penelitian maka dapat dilihat dari rata-rata produksi per hektar di empat lokasi penelitian diantaranya Kecamatan Labuapi sebasar 47,76 kw, Kediri sebesar 46,81 kw, Gerung produksi rata-rata per hektar sebesar 39,80 kw dan Narmada sebesar 39,22 kw.

Nilai produksi padi petani produsen di daerah penelitian secara keseluruhan per hektar sebesar Rp. 17.360.000.-, sedangkan rata-rata perluas lahan garapan petani sebesar Rp. 11.978.400.-.

Dari tabel 8.diatas, pendapatan usahatani padi yang diperoleh petani responden per hektar sebesar Rp.9.278.200.- dengan biaya produksi sebesar Rp.6.401.958.-.

Tabel 9. Rata-rata Produksi per hektar, Nilai Produksi, Biaya Produksi dan Pendapatan Usahatani Padi Lahan Irigasi MT. 2016/2017 di Empat Kecamatan Sampel Kabupaten Lombok Barat.

\begin{tabular}{|l|l|r|r|r|r|}
\hline No & \multicolumn{1}{|c|}{ Kecamatan } & \multicolumn{1}{|c|}{$\begin{array}{c}\text { Produksi } \\
(\mathrm{kw})\end{array}$} & $\begin{array}{c}\text { Nilai } \\
\text { Produksi } \\
(\mathrm{Rp})\end{array}$ & $\begin{array}{c}\text { Biaya } \\
\text { Produksi } \\
(\mathrm{Rp})\end{array}$ & $\begin{array}{c}\text { Pendapatan } \\
\text { (Rp) }\end{array}$ \\
\hline 1. & Labuapi & 47,76 & 19.104 .000 & 15.835 .025 & 3.268 .975 \\
2. & Kediri & 46,81 & 18.724 .000 & 12.737 .060 & 5.986 .940 \\
3. & Gerung & 39,80 & 15.920 .000 & 9.386 .350 & 6.533 .650 \\
4. & Narmada & 39,22 & 15.688 .000 & 9.471 .294 & 6.216 .706 \\
\hline
\end{tabular}

Selanjutnya pada Tabel 9.dijelaskan lebih rinci biaya yang dikeluarkan sekaligus nilai produksi dan pendapatan yang dicapai petani dimasing-masing Kecamatan. Dapat dilihat bahwa pendapatan usahatani rata-rata per hektar yang diperoleh petani di Kecamatan Labuapi sebesar Rp. 3.268.975.- Kecamatan Kediri sebesar Rp. 5.986.940.- Kecamatan Gerung sebesar Rp. 6.533.650.- dan Kecamatan Narmada Rp. 6.216.706,-. Sehingga dapat disimpulkan bahwa usahatani padi layak untuk diusahakan dan menguntungkan secara ekonomi karena memiliki (R/C Ratio)> 1.

\section{SIMPULAN DAN SARAN}

\section{Simpulan}

Berdasarkan hasil analisis dan pembahasan serta batasan pada ruang lingkup penelitian dan tujuan yang ingin diketahui, maka dapat disimpulkan 1).usahatani padi dilahan irigasi dilakukan pada MH dan MKI, dengan sistem tanam monokultur, varietas yang dominan adalah Invari 32. Selanjutnya pada tahap 
pengolahan lahan dan penanaman penggunaan tenaga kerja terbesar yaitu 40 HKO.Pemakaian pupuk belum berimbang dan tidak tepat dosis 2). Faktor-faktor produksi yang secara signifikan mempengaruhi tingkat produksi pada usahatani padi di lahan irigasi adalah luas lahan, benih, pupuk (Urea + SP36) dan pestisida 3). Rata-rata tingkat efisiensi teknis yang dicapai adalah 0,899 (89,9\%). Artinya, rata-rata produktivitas yang dicapai adalah sekitar 90 persen 4). Faktor-faktor yang mempengaruhi secara signifikan tingkat efisiensi penggunaan factor produksi adalah jumlah bidang persil, pengalaman berusaha tani, pendidikan kepala keluarga dan frekuensi tanam dalam satu tahun karena nilai t-hitung lebih besar dari t-tabel 1,96. 5). Pendapatan yang di terima petani dari usahatani padinya adalah Rp.9. 278.200,-/hektar dengan biaya produksi yang harus dikeluarkan rata-rata per hektar sebesar Rp. 8.081.800,- Oleh karenanya usahatani padi dilahan irigasi menguntungkan secara ekonomi karena nilai efisiensi usahanya (R/C) 1,15.

\section{Saran}

Dari hasil penelitian dapat disarankan: 1). pemerintah harus pengendalian laju alih fungsi lahan agar luas lahan sawah irigasi atau penguasaan lahan sawah petani tidak bertambah kecil dan Pemerintah daerah Kabupaten Lombok Barat harus tegas dalam impelementasikan Rencana Tata Ruang Wilayah (RTRW) yang sudah disusun; 2). Pemerintah secara bersama-sama dengan swasta mendorong dan memfasilitasi penerapan teknologi SRI (System of Rice Intensification)

\section{DAFTAR PUSTAKA}

Aigner, D.J, and Chu, S.F. 1968. On Estimating the industry production function American Economic Review, 58:226-239.

Badan Pusat Statistik. 2016. Nusa Tenggara Barat dalam angka. Mataram

Dinas Pertanian dan Tanaman Pangan NTB. 2001. Gema palagung. Provinsi Nusa Tenggara Barat . Mataram.

Nasir, M. 1981. Metode Penelitian. Ghalia Indonesia: Jakarta.

Rahmayati. 2008. Determinasi Efisiensi Teknis Penggunaan Faktor Produksi pada Usahatani Padi Lahan Irigasi Kabupaten Lombok Barat. Mataram

Soekartawi. 1987. Prinsip Dasar Ekonomi Pertanian Teori dan Aplikasi. Rajawali Pers: Jakarta. .2002. Prinsip Dasar Ekonomi Pertanian Teori dan Aplikasi. Rajawali Pers: Jakarta. . 2003. Metodologi Riset. Teknik dan Aplikasi. Grasindo: Jakarta.

Sudjana. 1983. Teknik Analisa Regresi dan Korelasi Bagi Para Peneliti. Tarsito: Bandung. 